\title{
Karl Przibram: Radioactivity, Crystals, and Colors
}

\author{
Wolfgang L. Reiter*
}

Karl Przibram is one of the pioneers of early solid state physics in the field of the interdependence of coloration effects and luminescence in solids (crystals, minerals) induced by radiation. In 1921 Przibram discovered the effect of radio-photoluminescence, the lightstimulated phosphorescence in activated crystals induced by gamma rays. In 1926 Przibram was the first to use the term, Farbzentrum (color center, F-center), and in 1923 he advanced the view of atomic centers as carriers of coloration. Being a pupil of Ludwig Boltzmann and Franz S. Exner, he dedicated his early work to condensation and conductivity phenomena in gases and Brownian motion. Under the influence of Stefan Meyer, he began his lifelong interest in mineralogy, setting up his own research group at the Vienna Radium Institute, which pioneered investigations on thermoluminescence and gave a first description of glow curves. Being of Jewish descent, Przibram had to leave Austria after the Nazis took power; he found shelter in Belgium and returned to Austria in 1946 as professor for experimental physics at the University of Vienna. This paper is a first attempt to give an overview of the cultural and scientific background of Przibram's life and science in context of the cultural and political developments from 1900 to 1950 in Austria.

Key words: Biography; mineral physics; coloration effects and luminescence in solids; Ludwig Boltzmann; Franz S. Exner; Stefan Meyer; Vienna Radium Institute; migration.

\section{Introduction}

The landscape of Austrian science from the last decades of the nineteenth century to the first third of the twentieth century is dominated by two towering figures, the physicist Ludwig Boltzmann (1844-1906) and the philosopher-scientist Ernst Mach (1838-1916), Boltzmann's good friend and philosophical adversary. To paraphrase Isaac Newton's saying, repeated in Robert K. Merton's most enjoyable book, it is fair to say that Boltzmann stood on the shoulders of (local) giants, his teacher Josef Stefan (1835-1893) and his paternal friend Josef Loschmidt (1821-

\footnotetext{
* Wolfgang L. Reiter is Honorary Professor for history of science at the Faculty of Historical and Cultural Studies of the University of Vienna; he received his $\mathrm{PhD}$ in nuclear physics from the Institut für Radiumforschung und Kernphysik, University of Vienna. His research interests are in the history of physics and the forced migration of scientists from Austria.
} 
1895). ${ }^{1}$ As a member of the generation prior to Loschmidt and Stefan, Christian Doppler (1803-1853) belongs to the first cohort of nineteenth-century physicists in the Habsburg Empire who established themselves after a major reform of the Austrian schooling system. Doppler later achieved general recognition and his name became a mainstay in twentieth-century sciences and applied technologies. Physics in Austria is known for the outstanding contributions of Doppler, Loschmidt, Stefan, Mach, Boltzmann and, much later, Erwin Schrödinger (18871961).

The Thun-Hohenstein reform of higher education in Austria in 1850 placed attention on a proper scientific education. Initiated by liberal scholars in the wake of the (failed) revolution of 1848, institutional innovations in the sciences were rolled out. These included the foundation of an academy of the sciences (Wiener Akademie der Wissenschaften, 1847), the establishment of the first geological survey on the continent (Geologische Reichsanstalt, 1849), the foundation of an institute for meteorology and geophysics (Zentralanstalt für Meteorologie und Erdmagnetismus, 1851), and improved conditions for teaching physics at the university level. Boltzmann benefitted from these institutional innovations, in particular the foundation of a new physics institute in 1850 , which was initially headed by Doppler and later by Stefan.

Boltzmann's younger colleague Franz Serafin Exner (1849-1926) could fully profit from these developments. The Exner-Circle, consisting of Exner, the undisputed father figure, together with his pupils and collaborators, had a lasting influence on the development of modern physics in Austria. ${ }^{2}$ This is an intriguing episode, which has attracted little historical attention until recently, after the Habsburg Empire and its scientific life became a focus for historians. ${ }^{3}$

Austrian science around 1900 still awaits a comprehensive study. Schorske's influential book Vienna around 1900 had little to say about the sciences. ${ }^{4}$ The exceptions to this lack of attention from historians of science are works devoted to the Institute for Radium Research, the "Radiuminstitut," in Vienna, which played a unique role in radioactivity research since 1910, and, most recently, an anthology on the Biologische Versuchsanstalt, the Vivarium, one of the first research institutes dedicated to a then-novel approach in experimental biology. ${ }^{5}$ The aim of this paper is to address this lacuna by providing a first comprehensive portrayal of the eminent Viennese scholar Karl Przibram (1878-1973), deputy director of the "Radiuminstitut," and his research program.

Karl Przibram's core research area was the interaction of radiation with crystalline materials and the various effects connected with this interaction, some of which Przibram and his collaborators observed for the first time. Hitherto, little attention has been devoted to the scientific work of Przibram and his group on the interaction of radiation with solids. Furthermore, it is a story of physics embedded in an exceptional scientific and cultural context, the period extending from the late Habsburg Empire to the Anschluss in 1938. It is the story of science and scientists exemplifying a broad spectrum of the social, political, and economic dimensions of 
their Viennese and Jewish background and culture. It is a story spanning from the heyday of Austrian liberalism to the days of the forced migration of so many scientists from Austria after March 1938, when the Nazis took power in the country. The story of Przibram and his working group at the Radiuminstitut in Vienna is not only a story about solid state physics, but also a story of Jewish life in Austria.

\section{Vienna's Jewish Bourgeoisie in Cultural and Scientific Contexts}

In December 1857, the young Emperor Franz Joseph I (1830-1916) decided to demolish the strategically obsolete fortifications that had previously saved Vienna's inner city from the 1683 siege by the Turks. This move signaled a new era of prosperity and political and cultural change. It marked the beginning of the period known as Gründerzeit, an era in which the Austrian-Hungarian liberal bourgeoisie dominated the political and cultural affairs of the Empire. Construction work on a new boulevard, the Ringstrasse, responded to the Emperor's order to connect the inner city with the adjacent districts where merchants, craftsmen, and petit bourgeois entrepreneurs plied their trade. This radical modernization of the city's landscape, which started in 1858 and persisted until fifteen years later when most of the buildings and palaces had been erected, signaled the promise of upward mobility for parts of the urban population. The construction of the new K. K. HofBurgtheater, the premier stage in the German lands, undertaken under the auspices of the Emperor and prominently positioned opposite the neo-Gothic Town Hall, began in 1874 and finished not earlier than 1888, a time span usually associated the construction of the religious buildings of the past. In close vicinity to the Burgtheater, the neo-renaissance building of the university at the Ringstrasse was opened by the Emperor in 1884. This building represented bourgeois pride and pomposity and had no space for the growing needs of the Vienna school of medicine, not to mention those of chemistry or physics. It took another twenty to thirty years before the institutes of chemistry and physics got their own new premises.

In 1860 Friedrich Schey von Koromla (1815-1881) purchased a parcel of land from a member of the Imperial family at the Ringstrasse next to the Court Opera House to erect his own city palace. Four years later, a splendid building was finished. ${ }^{6}$ Born in Güns (now Köszeg, Hungary) into a well-to-do Jewish family, Schey studied law in Ödenburg (now Sopron, Hungary) and moved to Vienna to attend the Polytechnicum (today the Vienna University of Technology) in 18311832. He subsequently joined the bank Wertheimstein before leaving Vienna to work with the family trading house in Güns. Returning to Vienna, he became the banker of Archduke Albrecht, a contact that facilitated Schey's profitable armysupply business. His business career in the period from 1850 to 1870 was outstanding. He held positions in the railroad, textile, and banking industries; he was director of the Austrian National Bank, ran his own silk production operation in 
Slavonia, was director of the Vöslau worsted factory, and served various boards of banks, railways, and factories; he founded the Vienna Commercial Academy and the Vienna Municipal Theatre, was involved in the foundation of the Vienna Musikverein, and was a renowned collector of paintings and rare books. He was, in short, the model of a successful businessman and patron of the arts in Vienna.

Why is this of any interest for our purposes? A good part of scientific life in late-nineteenth and early twentieth-century Vienna was carried out by scions of liberal bourgeois families of Jewish background, who came to wealth during the liberal era of the Gründerzeit. Karl Przibram is an eminent example of this sort of family background.

Friedrich Schey had seven children: Emma, Stefan, Charlotte, Josef, Paul, Alexander, and Mathilde. This second generation of children partly evaded the business jobs of their families, pursuing academic professions instead. Josef Schey (1853-1938) became professor of civic law at the Universities of Graz and Vienna. ${ }^{7}$ In 1886 Mathilde Schey married Adolf Lieben (1836-1914), a professor of chemistry at the University of Vienna and founder of the school of chemistry in Vienna. Adolf was the son of Ignaz Lieben (1804-1892), a personage of similar importance and commercial success as Friedrich Schey. Charlotte Schey von Koromla (1851-1939) was married to Gustav Przibram (1844-1904) from Prague in 1871. Members of the Schey family were married to wealthy Jewish families of the Austro-Hungarian Empire, to members of the Ephrussi, Rapoport von Porada, Goldschmidt-Rothschild, Lieben, Landauer, Worms, and Lang families. The Przibrams were less wealthy by far than the Ephrussis or Liebens, whose banking houses were rivaled only by the Vienna branch of the Rothschild family.

The years after Austria's defeat in the war with Prussia in 1866 brought outstanding economic growth under liberalism, but at the expenses of the lower classes. This economic development came to a sudden halt with the stock market crash of May 1873, coinciding with the Vienna World Fair, which had opened that same month. A cholera epidemic raged in the city's slums. But the economy recovered thanks to state interventions, and during the periods 1879 to 1883,1886 to 1890 , and finally from 1896 to 1914, the Austrian-Hungarian Empire experienced remarkable economic booms.

The late 1880s and early 1890s were marked by a sharp rise in aggressive antiSemitic rhetoric in the form of a populist political program represented by Karl Lueger (1844-1910), major of the city of Vienna from 1897 to 1910, together with the explicitly anti-Semitic political party, the Christlichsoziale Partei, founded by Lueger in 1893. From these times onward, religious anti-Judaism became racial anti-Semitism and had a strong influence in academia, and the reproduction of its personnel in particular. ${ }^{8}$ As a reaction to the growing discrimination in public life and academia, many members of the highly assimilated liberal Viennese Jewish bourgeoisie broke with a scarcely practiced religious tradition and converted to Christianity, be it Protestant or Catholic. Karl Przibram was not among them. 
One member of the Schey family, Josef Unger (1828-1913), ranked highly among those who profited from assimilation: Unger's outstanding carrier as an academic and politician included the necessary ultimate step of assimilation when he agreed to be baptized. ${ }^{9}$ Unger was a professor of law at the University of Vienna, founder of the Austrian jurisprudence and German-liberal politician at the Reichsrat (house of representatives). During the heyday of liberalism he was minister without portfolio from 1871 to $1878-1879$ in the government of prime minster Count Adolf Carl Daniel von Auersperg (1821-1885). It is worth mentioning that although the liberals suffered heavy losses during the first direct election of the Reichsrat and lost their majority in 1879, the influence of the liberals in commerce and culture still dominated.

\section{Karl Przibram's Early Years}

Gustav Przibram, Karl Przibram's father, made his fortune in the textile industry in the Czech lands and was a temporary German representative to the Bohemian Parliament (Landtag) in Prague. As a homme de lettres he published under the pseudonym Hans Walter. ${ }^{10}$ Gustav and his wife Charlotte raised four children, born between 1873 and 1881: Walter Salomon (1873-1898), ${ }^{11}$ Hans Leo (18741944), Karl Gabriel (1878-1973), and Friederike Emilie, nèe Lederer (18811946). ${ }^{12}$ In a short autobiographical sketch Karl characterized the milieu of his childhood:

The dominant spirit of my paternal home was that of the educated Jewish bourgeoisie of the liberal era, with its unconditional faith in progress and its open mindedness for all achievements in art and science. Among my uncles there where the jurists Josef Unger and Josef Schey as well as the chemist Adolf Lieben. My father himself, incidentally a gifted poet and full of deep social feeling, was very much interested in technical applications of the sciences. He took part in the invention of a galvanic battery, by means of which in the beginnings of the 1880 s he illuminated our flat. ${ }^{13}$

No better short description could be given of the Zeitgeist prevalent during Karl's formative years: unconditional faith in progress; openness to all achievements in the arts and sciences; strong interest in technical applications and science-based innovations. No wonder the young Karl became interested in conducting his own physics experiments at home to rival his father's invention of a galvanic battery. He was allowed to install his own little "home laboratory" where he was able to repeat Nikola Tesla's experiments and became fascinated with the Lichtenberg figures that stoked his deep aesthetic sensitivity in the sciences.

From 1889 to 1897 Przibram attended the Akademisches Gymnasium, at his time one of Vienna's most prestigious secondary schools, where he took his final examinations, the Matura in 1897. In the same year, he matriculated at the University of Vienna to study physics, chemistry, and mathematics from winter 
term 1897 until winter term 1898. Two years earlier, in 1894, Ludwig Boltzmannback in Vienna from Munich-had accepted the chair of theoretical physics at the University of Vienna. With Boltzmann as the theoretician and Franz S. Exner occupying the chair in experimental physics, Przibram profited from both of these outstanding scholars and gained a profound basis for his education in the physical sciences, theoretically as well as experimentally. Besides Boltzmann and Exner, he named the mathematicians Gustav von Escherich (1849-1935) and Franz Mertens (1840-1927) as well as the chemists Cäsar Pomeranz (1860-1926) and his uncle Adolf von Lieben as his teachers during his studies in Vienna. ${ }^{14}$

Przibram did not finish his studies in Vienna, but went to Graz in summer of 1899 to work with Leopold Pfaundler (1821-1885), Boltzmann's successor at the University of Graz in 1891 when Boltzmann moved to Munich the year before. ${ }^{15}$ Przibram received his $\mathrm{PhD}$ in July 1901 after having finished his experimental doctoral dissertation (Photographische Studien über die elektrische Entladung). Back in Vienna, the young $\mathrm{PhD}$ complemented his physics training by attending a practical course in organic chemistry and physical chemistry at the II. Chemisches Institut of the University of Vienna at Währingerstrasse 10 in Vienna's 9th district, which his uncle Adolf von Lieben had chaired since 1875.

From spring 1902 until summer 1903 Przibram visited the Cavendish Laboratory in Cambridge, UK, working with J. J. Thomson (1856-1940), who welcomed the young scientist into his family, working on the conductivity in gases as a follow up of his experimental work in Graz. The close contact with Thomson and especially with C. T. R. Wilson (1869-1927) and O. W. Richardson (1879-1959) during his postdoctoral stay at the Cavendish was of lasting influence to his experimental work on condensation and conductivity during the coming years. Upon returning

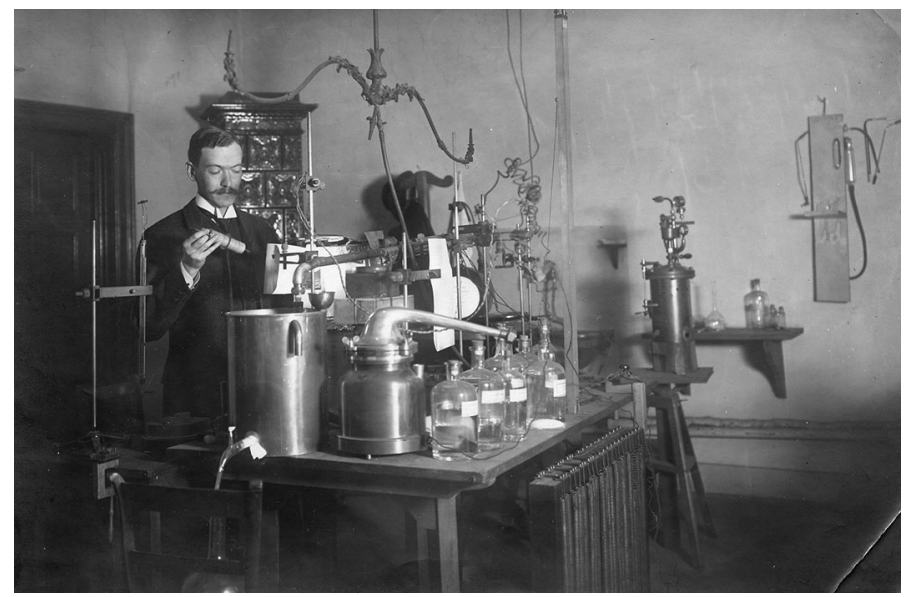

Fig. 1. Karl Przibram at the Physics Institute at Türkenstrasse ca. 1910. Archive of the author 
Vienna, he started to work at the old physics institute at Türkenstrasse 3 (figure 1) in Vienna's 9th district at Boltzmann's Institut für theoretische Physik in close contact with his friend and distant relative Stefan Meyer (1872-1949). ${ }^{16}$ In those days, Lise Meitner (1878-1968) was working next door on her doctoral thesis under Exner's and Meyer's supervision.

An outstanding example of an innovative initiative in the sciences has to be briefly mentioned in the context of Karl Przibram's role as a patron of science. Three members of the Jewish Viennese bourgeoisie had the vision to establish a unique research institution at their own expenses: the plant physiologist Wilhelm Figdor (1866-1938); the botanist Leopold von Portheim (1869-1947), a cousin of the Przibram's; and Hans Leo Przibram (1844-1944), a biologist and Karl Przibram's younger brother. In 1902 Hans Przibram, financially supported by his brother Karl, purchased a pseudo-renaissance building, which had hosted a bankrupt animal show situated in the Vienna Prater, the former hunting ground of the Habsburg Emperors, before it was committed to the public by Emperor Josef II (1741-1790). Figdor and von Portheim contributed money to equip the research facility. Within the walls of this splendid building, they established a private research facility dedicated to experimental biology, the Biologische Versuchsanstalt. ${ }^{17}$ This private research institute was guided by an innovative research program strongly focused on an experimental methodology and a synthesis of interdisciplinary research in biology, zoology, botany, plant physiology, chemistry, and even physics to investigate questions of developmental biology on a very broad basis. Systematic studies of living species were absolutely novel at that time compared to university research predominantly done on dead specimens. The Biologische Versuchsanstalt signaled a paradigm shift in the biological sciences. In 1914 the owners entrusted the institute to the Vienna Academy of Sciences; Karl Przibram contributed a further sum of 100,000 Kronen (crowns) for future refurbishment of the institute. ${ }^{18}$

\section{Early Work on Conductivity, Condensation, and Atomism}

In 1905 Przibram took the next step of his academic career, becoming Privatdozent (lecturer) in experimental physics on the strength of his work on Büschelentladungen, impulse-shaped discharges between electrostatic charged surfaces. The title of his probation lecture (Probevortrag) was Über polare Unterschiede in den elektrischen Erscheinungen (On Polar Differences in Electrical Phenomena). Over the next few years, Przibram was intensively occupied with work on condensation phenomena, a field of research he first became familiar with during his stay in Cambridge from the work of C. T. R. Wilson on ions in gases as condensation nuclei and his insight that the conductivity in gases is due to ionization, in particular. These investigations prepared ground for the development of the cloud chamber, long one of the most successful instruments in radioactivity research. Przibram investigated the condensation process influenced by the different role of positive and negative ions, the ion mobility, and performed measurements of charges on vapor droplets. 
Stimulated by Felix Ehrenhaft (1879-1952), ${ }^{19}$ Przibram's colleague at Exner's institute, and his experiments for the determination of the value of the smallest electric charge, the elementary quantum of electricity, Przibram during the years 1910 and 1911 undertook a series of measurement repeating Robert A. Millikan's (1868-1953) and Ehrenhaft's experiments by using vapor droplets (instead of oil droplets à la Millikan or ultramicroscopic silver particles à la Ehrenhaft), both with and without an external electric field. ${ }^{20}$ Between April 1910 and March 1911 he published six papers. Although his experiments had been unable to decide the question of whether there are smaller charges then those measured by Millikan (smaller then $e=4.7 \times 10^{-10} \mathrm{esu}$ ), Przibram did not follow Ehrenhaft's speculations about "subelectrons" with a charge of $q=2 / 3 e^{21}$

At the Solvay Congress in 1911, Friedrich Hasenöhrl (1874-1915) "pointed out that Przibram had never adopted Ehrenhaft's views on the existence of subatomic charges." ${ }^{22}$ Already at the 1911 Solvay Congress, Albert Einstein (1879-1955) reported on the work Edmund Weiß in Prague, who found that Stokes's Law does not apply to the metal colloid (silver) particles used by Ehrenhaft, and therefore Ehrenhaft's determination of the electric charge could not be valid. ${ }^{23}$ In stark contrast to Ehrenhaft's persistence on "subelectrons," Millikan remarked in 1917, referring to the experiments of Weiß and Przibram, that the scientific community "ceased to concern itself with the idea of a sub-electron." 24

As late as his years in exile in New York (1939-1947), Ehrenhaft wrote in his Curriculum Vitae: "Later, but independently, Millikan, in the course of his famous work, determined the charge on large oil drops in condensors of much greater dimensions (20 cm diameter) and identified these values he obtained with the electronic charge. From the difference between these results there arose a controversy which has not been settled yet." 25 Obviously, Ehrenhaft never gave up belief in his erroneous experimental results, long since dismissed by the scientific community.

It is worth indulging in a brief excursion on the question of Ehrenhaft's "subelectron." It is interesting to note that Ehrenhaft, when determining experimentally the electric charges of the droplets, had not been aware of his implicit assumption of spherically symmetrical particles. Given that a part of the particles measured separately had been aggregated particles of two spherical symmetrical particles, these particles exhibit an electric dipole moment of random orientation in the electric field of the condenser. Since the air resistance is different regarding the sedimentation velocity of these aggregates in the electric field, corrections (shape factors for rotation ellipsoids) have to be applied, which would yield charges of values roughly $2 / 3$ of $e$. Ehrenhaft never abandoned his assumption of "of the subelectron." Shape factors for rotational ellipsoids had been calculated by C. Oseen in 1927. ${ }^{26}$ Shape factors for prolonged ellipsoids with a relation of the axes of 2 can be considered as approximations of double spheres, as in the case when selenium particles are used. This renders a correction factor for the particle radius of 0.870 and for the particle charge of 0.658 , approximating a ratio of $2 / 3 .^{27}$ 
Next, Przibram (figure 2) turned his attention to Brownian motion of nonspherical particles, demonstrating the validity of Einstein's formulae for unordered motions. In 1913 Przibram did experimental work on random biological motion: the self-propelled random motion of protozoa. ${ }^{28}$ His work on Brownian motion has been recently discussed in the literature in context of Einstein's publication of $1905:^{29}$

Brownian motion has been known for as long as the microscope, and before the kinetic theory of heat it was natural to assume that "since it moves, it is alive." Brown killed that idea. But after Einstein in 1905 had published his theory for Brownian motion, Przibram in 1913 demonstrated that this theory describes also the self-propelled random motion of protozoa.... By tracking the trajectories $x(t)$ of individual protozoa ... Przibram demonstrated that the net displacement $x(t)-x(0)$ averages to zero, while its square satisfies the relationship known for Brownian motion, $\left\langle d(t)^{2}>=2 n_{\text {dim }} D t\right.$, where $\mathrm{n}_{\text {dim }}$ is the dimension of the space in which the motion takes place.

In Einstein's theory, $D$ is the diffusion coefficient, and satisfies his famous relation $D=k_{b} T / \gamma_{0}$ [fluctuation-dissipation theorem, $k_{b} T$ Boltzmann energy, $\gamma_{0}$ Stoke's

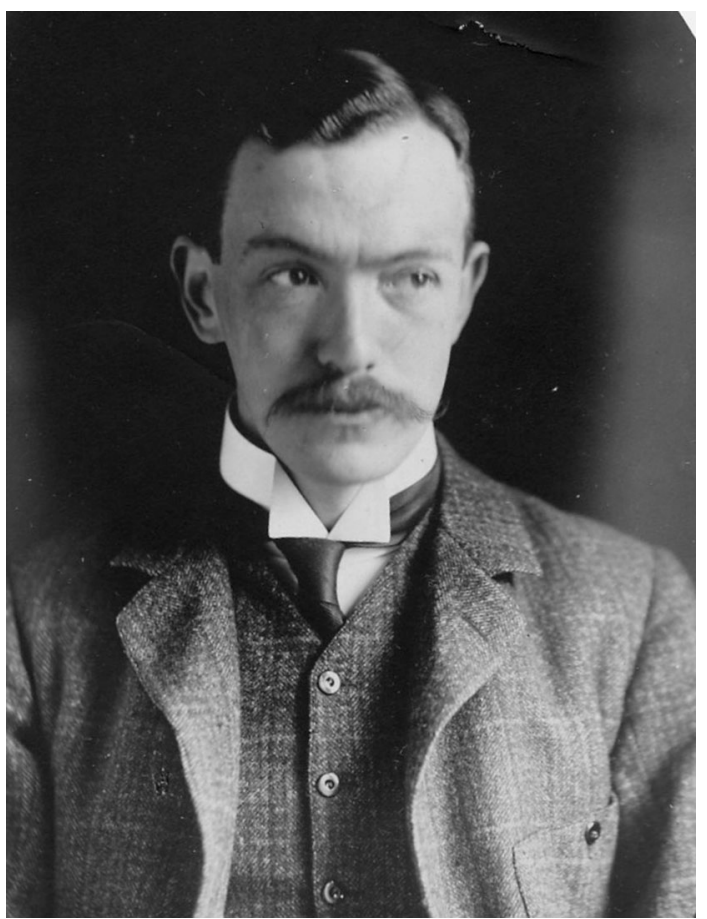

Fig. 2. Karl Przibram around 1905. Archive of the author 
friction coefficient]. Przibram found a value for $D$ which was much larger and much more sensitive to changes in temperature than Einstein's relation states. He used this as proof that it was not just Brownian motion that he had observed.

If Przibram, a biologist [sic], had used a better time resolution by marking out points ... more frequently than every four seconds, he might also have gotten ahead of the physicists in theoretical developments. But he was drawing by hand, marking time to a metronome, so marking points closer to $1 \mathrm{~Hz}$ must have been a challenge. ${ }^{30}$

The experimental work done in Vienna on the charge of the electron, the quantum of electrical conductivity, and in particular on Brownian motion was a sequel to the famous fight between Boltzmann and Mach for and against atomism and (Wilhelm Ostwald's) energeticism; this was demonstrated by the interest of the Viennese scientists around Franz S. Exner in investigating fluctuation phenomena in the light of kinetic theory. Two members of the Exner Circle studied Brownian motion: Felix M. Exner conducted experimental investigations in 1900 on the relation of the kinetic energy of suspended particles to the temperature of the liquid, and Marian von Smoluchowski pursued theoretical work, giving a molecular account of Brownian motion in 1906, one year after Einstein's paper on the subject. $^{31}$ The strong interest of the Viennese physicists-spurred by Franz S. Exner-on the molecular/atomistic structure of nature was rooted in Boltzmann's conviction to believe in the reality of atoms, an epistemological and ontological viewpoint not shared by all scientist around 1900 .

Einstein, a good friend of Ehrenhaft, clearly saw the shortcomings of Ehrenhaft's experimental setup in 1911. Przibram did not take sides explicitly, but Hasenöhrl, Boltzmann's successor at the chair of theoretical physics in Vienna, explicitly defended Boltzmann's atomistic approach. After Boltzmann's suicide in 1906, among his former students in Vienna the Boltzmann-Mach controversy on atomism was not any longer an epistemological clash of irreconcilable concepts but a question for the experimental table. Jean Perrin (1870-1942) closed this chapter for good in 1911, giving evidence through his experimental work on Brownian motion that the atomistic structure of matter was beyond further doubt. $^{32}$

\section{At the Radium Institute, 1912-1938}

In 1910 the Institut für Radiumforschung opened its doors. Karl Kupelwieser (1841-1925), one of the developers of heavy industry in the Czech lands (Wittkowitzer Eisenwerke) and brother-in-law of Karl Wittgenstein (1847-1913), the father of Ludwig Wittgenstein (1889-1951), devoted a considerable sum to the Vienna Academy of Sciences to erect and furnish a building for research on the element radium, which had recently gained economic and scientific prominence. At that time, Austria was in the comfortable position of a monopolist provider of 
the mineral pitchblende mined in St. Joachimsthal (today Jachymov, Czech Republic), the mother ore for the extraction of uranium. After the discovery of radioactivity of the elements polonium and radium in 1898 by Marie and Pierre Curie, uranium gained high market value. Kupelwieser's ambition was to secure predominance for his country in investigating the properties of these recently discovered elements, blending scientific with economic goals. We remember Przibram's narrative on liberal values in the 1880s: scientific progress, technological innovation, and economic development, fostered by enlightened liberal patrons. These values remained valid in 1910-still times of security for the wealthy liberal bourgeoisie.

The acting director of the newly established institute of the Vienna Academy of Sciences was Exner's assistant, Stefan Meyer. He was charged with the planning and supervision of the new institute and its furnishing. Meyer had no role model for this task. ${ }^{33} \mathrm{He}$ was the right person to manage this job and demonstrated his outstanding abilities as a talented organizer of research. Meyer was decorated with the Franz-Joseph-Order in recognition of his service for science in the public interest in the year in which the new institute opened.

Shortly after the opening of the Radium Institute, Przibram was invited by his friend Meyer to join the new institute as a private scholar, an offer Przibram could afford easily. Given the unique research opportunities of the institute, with its new instrumentation and its unique irradiation source of 4 grams of radium chloride, Przibram changed his field of research from condensation phenomena to the investigation of radiation effects in solids. It is a justifiable assumption that Meyer proposed this field of research to Przibram.

Already in 1909, still at the old physics institute at Türkenstrasse 3, Meyer investigated the influence of Becquerel-radiation on the mineral Kunzite, a sample of which had been supplied to him by his distant relative, the famous mineralogist and crystallographer Victor Mordechai Goldschmidt (1853-1933) of Heidelberg. Using a strong 1-gram radium chloride preparation for irradiating Kunzite, Meyer observed color changes and the intense fluorescence coming along with it. Meyer's findings were published in two short notices. ${ }^{34}$ This pioneering work laid the basis for Przibram's life-long interest in color changes and luminescence phenomena in solids. $^{35}$

\section{Przibram's Research Group}

Przibram already had established himself as a prolific researcher with no less than thirty publications during the years 1899 to 1912, mainly on conductivity in gases, condensation phenomena of positive and negative ions, and ion mobility in general, besides his investigations on Brownian motion. In 1912 he started his research on the interaction of radiation with crystalline structures, in particular coloration and luminescence caused by radioactivity as one of the freelance researchers at the Radium Institute. No doubt, he was financially independent and able to maintain 
his life as a private scholar. At that time, Victor Franz Hess (1883-1964) had been the only fully paid assistant (Adjunkt) at the new institute, and the year 1912 was marked by Hess's discovery of cosmic radiation, which gained him the Nobel Prize in Physics in 1936.

Przibram's first paper after Meyer invited him to work at the Radium Institute was dedicated to his future research interests on the coloration of salts and was published in 1914 with Meyer as co-author. ${ }^{36}$ It should be noted that the research interest in Vienna on alkali halides as a "model substance" for crystal coloration and luminescence by radiation (using radioactivity) was fostered by the availability of strong radioactive sources to manipulate certain coloration properties in solids; this starting point of intense investigations in Vienna seems to be different compared to similar investigations by Philipp Lenard (1862-1947), Wilhelm Conrad Röntgen (1845-1923), and especially Robert Wichard Pohl (1884-1976) and his Göttingen school of alkali halide research, which had its origin in research on photoelectric conductivity. ${ }^{37}$ Przibram's as well as Pohl's and Lenard's interest in the physics of the emission of light in gas discharges could be considered as a starting point of their later research interests in solid state physics and luminescence, especially the investigations of alkali halides. ${ }^{38}$

In 1914 Przibram was awarded the Haitinger Award of the Vienna Academy of Sciences. In 1916 he achieved the title of an extraordinary professor of physics, a position that did not pay, but conferred a certain academic status. In 1920 he became an assistant at the Radium Institute, a position that was moderately paid. Finally, in 1927, he became extraordinary professor (ausserordentlicher Professor) - the next step in the academic hierarchy-in times when anti-Semitism in academic circles limited opportunities for further promotions and university positions. The year 1916 was marked by his marriage to Susanne Louise Tressler (1895-1918), the daughter of one of the most venerated actors of the Burgtheater, Otto Tressler (1871-1965), later one of the heroes of the early film industry. Heinrich (Heini) was their first and only child, born two years after their marriage. In 1918 Susanne died. One year after this loss, Przibram married Elisabeth (Else) Tongarelli (1887-1970), a cousin of his first wife. Erika Renate, born in 1926, was Przibrams second child. ${ }^{39}$ In 1929 Przibram was awarded the prestigious Ignaz-L.Lieben Prize of the Vienna Academy of Sciences, which had been awarded for the first time to Josef Stefan in $1865^{40}$

Przibram's research program can be characterized as follows: (1) investigations of the phenomena of the interdependence of coloration effects and luminescence in solids (crystals, minerals) induced by radioactive radiation (radio-(photo)luminescence) and (2) investigations of the underlying mechanisms of coloration effects and their dependence on the properties of the crystal structure as a function of the disturbance of the crystal structure by thermal (thermo-luminescence) and mechanical (tribo-luminescence) influences.

In 1921 Przibram discovered the effect of radio-photoluminescence, the lightstimulated phosphorescence in activated crystals induced by gamma rays. ${ }^{41}$ This 
new effect underlined the fact that the stimulation of fluorescence or phosphorescence by light is dependent on the pre-history of the irradiation of the sample. So, the name-giving blue fluorescence of fluorite now could be understood as just an example of this effect. Today, this effect is used in dosimetry, since the emitted intensity of light is proportional to the number of luminous centers and to the incident dose.

These luminous centers had a rather long career as hypothetical carriers of the absorption of radiation (color) going back to Lenard's term Zentren for the carriers of phosphorescence. The theoretical-hypothetical conception of color centers in the mid-1920s was formulated by Gudden and Pohl: "The carriers of the coloration, termed centers for short, are non-microscopic structures with a simple characteristic absorption spectrum." 42 In 1926 Przibram was the first to use the term, Farbzentrum, and already in 1923 he had advanced the hypotheses of atomic centers as carriers of coloration. ${ }^{43}$ In other words, these color centers were considered to be (intrinsic) point defects in the crystal lattice characterized by their absorption spectra.

Working on radio luminescence and radio photoluminescence together with the Austrian-Bulgarian physicist Elisabeth Kara-Michailova (1897-1968), Przibram for the first time observed the repeated emission of light, that is, peaks (maxima) of the thermoluminescence light spectra, when the sample was continuously heated. Przibram and later Urbach firmly established this observation as a method, and called these glow peaks-as they are called today-Buckel. ${ }^{44}$

Franz Urbach (1902-1969) worked with Przibram from 1926 to 1931 on photoluminescence and thermoluminescence and gave a first comprehensive description of the glow curves (Leuchtkurven, Buckel) together with theoretical attempts referring to the Lockerstellenhypothese, a hypotheses to explain transport processes (diffusion and ionic conduction in ionic crystals) in crystal lattices using the concept of "loosened positions" (aufgelockerte Positionen) in the crystal lattice caused by various disturbances (for example, thermal movement), first formulated in Przibram's group by George de Hevesy (1885-1966) in 1922 and further developed by the Viennese theoretical physicist Adolf Smekal (1895-1959) in 1925 ("crystal lattice pores," Kristallgitterporen) and 1927 ("porous regions," Lockerstellen). ${ }^{45}$ The explanatory power of Smekal's (over)ambitious hypotheses to explain a broad range of properties of the crystalline state soon came under dispute but nevertheless got friendly acceptance by his Viennese colleagues and contributed to Przibram's understanding of Farbzentren (F-centers) in 1926, "the first precise hypotheses on the atomic structure of a color center." 46

As mentioned above, Urbach published three paper in 1930 on the luminescence of halides and measured glow curves using an improved experimental setup; these papers (the third co-authored by his good friend Georg Schwarz) are now considered seminal for the further development of the method using thermoluminescence glow-curves in dosimetry and archeometry. ${ }^{47}$ Urbach's further investigations were dedicated to radio-triboluminescence, infrared sensitive 
phosphors and the temperature and form dependence of absorption edges in solids.

Przibram's research group may be characterized by two aspects: first, the overall number of collaborators, and second, the number of publications. Using the references in his 1953 monograph as a data base (929 entries), ${ }^{48} 53$ persons working at the Radium Institute (figure 3) can be identified as members (authors or co-authors) of his research team during the years 1914 to 1938; they produced about 134 research papers at an average annual rate of 5.5, roughly a quarter of them published by Przibram himself. As a general trait of the Radium Institute, the percentage of women in Przibram's group was rather high, 36 percent. Another figure is disconcerting and a deplorable fact: 17 percent of Przibram's team (including himself) had to leave the country after the Nazis took power in Austria in 1938.

The high number of collaborators is due to the fact that the overwhelming proportion of them had been working on their $\mathrm{PhD}$ theses (Dissertationen) at the Radium Institute. Among them we find Lise Meitner's nephew, Otto Robert Frisch (1904-1979) — certainly the most prominent of Przibram's students regarding Frisch's later scientific career-who finished his dissertation under Przibram's supervision in close collaboration with his friend Urbach in $1926 .{ }^{49}$

It was around the time when quantum mechanics was being developed, 1925 to 1927, that the young Victor F. Weisskopf (1908-2002), during his studies at the University of Vienna, made a short detour into experimental physics at the Radium Institute. Here is his testimonial:

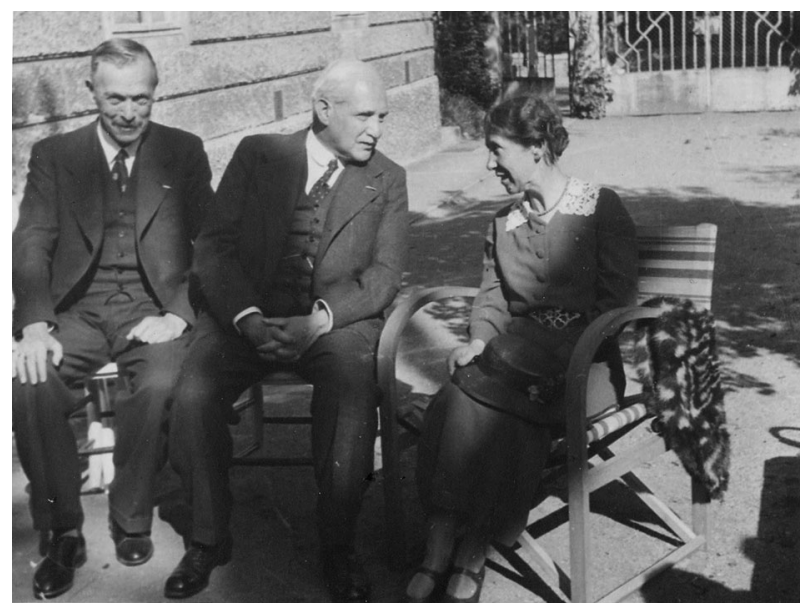

Fig. 3. Karl Przibram, Stefan Meyer, and Ellen Gleditsch (from left to right), Vienna around 1935 at the courtyard of the Radium Institute. Courtesy of the Österreichische Zentralbibliothek für Physik in Wien 
I was able to discuss some of these things (quantum mechanics) with Franz Urbach, a friend who was a few years older than I and already had a postdoctoral position in physics at the university. He asked me to help him with his experiments, and I enthusiastically agreed to do so. This was one of the few periods in my life when I participated in experimental physics. We tried to do something that today is called nonlinear optics. We measured the optical properties of special crystals doped with metal atoms to try to find out whether the properties changed with the intensity of light. With the equipment available at that time we did not find any changes. Had we had the intensity of modern lasers at our disposal, we would have found interesting effects. Urbach was also just learning about quantum mechanics, but my contact with him certainly deepened my understanding and interest in physics and in the philosophical implications of science.

In addition to his interest in science, Franz was a musician who lead a choir specializing in old music. I joined the choir with as much enthusiasm as I had joined his experiments in the laboratory. ${ }^{50}$

In 1931 Urbach became head of the newly established radiation department (Radiumstation) at the municipal hospital Lainz in Vienna, equipped with not less than five grams of radium for diverse cancer treatments. Having been accused by the clerico-fascist regime since 1933 in power in Austria of having been pushed into his position as a fellow traveler of the Social Democratic Party, Urbach was dismissed in 1934 and he-now unemployed-returned to the Radium Institute as a freelance researcher.

Counting the integral frequency of publications per person (greater than five) we can easily identify a core group of Przibram's team, consisting of Herbert Eduard Haberlandt (1904-1970), J. Hoffmann, Berta Karlik, Franz Urbach, and L. Wieninger. Haberlandt was a mineralogist and joined Przibram's group as an unemployed postdoc and freelance collaborator in the years 1933 to 1936 as did Urbach who got his doctorate in $1926 .{ }^{51}$ Berta Karlik had occupied one of the few payed posts (wissenschaftliche Hilfskraft) at the Institute since 1933.

From 1933 on, systematic investigations of the fluorescence of fluorite and the special role of bivalent rare-earth elements for coloration were undertaken by Przibram, Haberlandt, Karlik, and Elisabeth Rona (1890-1981). It could be demonstrated that blue fluorescence is radio-photofluorescence due to bivalent Europium, yellow-green low temperature-fluorescence due to bivalent Yttrium, red light due to bivalent Samarium and Thulium, as well as further investigations of the coloration of halides and the dependence of coloration on the growth rate of crystals.

From early on, starting with the investigations of blue rock salt in nature, the coloration of alkali halides had been a core interest of Przibram and his group, because "luminescence acquired the character of a model for many solid-state theories after Bohr's ideas [Bohr's atomic model of 1913] were accepted." 52 
Different from R. W. Pohl's research program first in Berlin and later at the University of Göttingen, the Viennese research had been barely interested in the (external) photoelectric effect and its connection with luminescence, or, more generally, the diffusion and ionic conduction in ionic crystals, with Hevesy being an exception for his aforementioned 1922 hypotheses of loosened positions. A somewhat farfetched explanation could invoke Przibram's intense aesthetic inclination for coloration phenomena, together with his moderate interest in technological applications (with Urbach as an exemption). As an aside, it is worth mentioning, that the theoretical physicist Hans Thirring (1888-1976), working next door at the Institute for Theoretical Physics of the University of Vienna, was highly engaged in developing selenium photocells for diverse applications, among others one of the first movietone sound systems. ${ }^{53}$ As sometimes happens, theoreticians and experimentalists lived in separate universes.

To conclude this short sketch of Przibram's research group and their findings, it seems worthwhile to add a few remarks to characterize the working relationships within his group. The Hungarian physicist Elisabeth Rona, working as a freelance scientist in Przibram's group from the middle of the 1920s, provided a lively picture of the family-like, collegial relationships typical of the Radium Institute:

The atmosphere at the institute was most pleasant. We were all members of one family. Each took an interest in the research of the others, offering help in the experiments and ready to exchange ideas. Friendships developed that have lasted to the present day. The personality of Meyer and that of the associate director, Karl Przibram, had much to do with creating that pleasant atmosphere. $^{54}$

Meyer and Przibram-highly cultured, cosmopolitan, and of similar family backgrounds - formed a unique atmosphere by a flat organizational structure guided by tolerance, openness regarding the choice of research problems, and close personal relationships, of which Weisskopf gives an example when he mentions playing music together. ${ }^{55}$ (Even in my days as a student and assistant at the Radium Institute, we had been using the term "Radiumfamilie" (radium family), although with a sort of ironic undertone!) As briefly mentioned above, the gender ratio in radioactivity research in Vienna was a singular characteristic of the Radium Institute compared to Rutherford's Cavendish Laboratory or Marie Curie's Institute Radium in Paris. The percentage of women in relation to the total number of researchers at the Radium Institute between the years 1919 and 1934 was thirty-eight, a number that even today is exceptional. ${ }^{56}$

\section{Finis Austriae-Years in Exile}

In March 1938, Austria was wiped off the map as an independent state when Nazi Germany occupied the country and Hitler declared Austria part of the German Reich in his speech at the Heldenplatz on March 15, 1938, frenetically cheered by 
an enthusiastic crowd of Vienna's population. The first transports of political adversaries of the Nazis and of people of Jewish decent to the Dachau concentration camp followed on April 1 and 2.

The cleansing of the universities of political adversaries of the Nazis and of staff of Jewish decent had been well prepared by members of the illegal Nazi party and its fellow travelers and was now accomplished at high speed and with great efficiency. On March 22, the academic staff of the University of Vienna was summoned for an oath to the Führer and Reichskanzler, Adolf Hitler. This oath was compulsory for all civil servants. On March 21, Przibram wrote a few dry and formal lines to the rectorate of his university: "I will not appear on Tuesday, March 22 for the swearing in, since as a Jew following paragraph 3, section 2 of the proclaimed announcement in the law gazette for Austria Z.3/1938 I am not to be sworn in. Very respectfully, Karl Przibram (figure 4)."57

On April 22, 1938, a long list was issued by the Ministry of Education and sent to the Dean of the Philosophical Faculty with names of persons to be dismissed. In physics, about one third of the professors and lecturers lost their positions, among them Stefan Meyer and Karl Przibram; one fourth of the staff of the Radium Institute had to leave. ${ }^{58}$ For a short period, Meyer and Przibram were tolerated as "guests" at the Radium Institute until one of the Nazis insisted that they had to leave the institute where they had worked for nearly three decades.

In March 1938, Przibram's son Heini had left Vienna for England, where he was taken care of by the Vienna-born chemist Friedrich Paneth (1887-1958) and his wife when he arrived in London and found shelter in Hartlepool, thanks to an English friend of the family. ${ }^{59}$ Meyer's son Fred was sent to relatives in England in April $1938,{ }^{60}$ a clear indication that Przibram, as well as Meyer, clearly saw the threat for Jews living under Nazi dominance well in advance of the November 1938 Pogrom, which, beyond societal and economical repressions, unmasked the Nazis' murderous intentions. In 1939 Przibram's daughter Erika, accompanied by her mother, was sent to England. Thanks to the Society of Friends (Quakers) and the Society for the Protection of Science and Learning, Erika found a surrogate family with Professor Pear in Manchester. Her mother Else (of “Arian” decent) went back to Vienna to be at the side of her husband Karl.

Franz Urbach, who held a patent on infrared vision, which was considered of military value by the Nazi authorities and was therefore denied permission to leave the country, finally was allowed to emigrate due to interventions of one of his collaborators, who was a member of the Nazi party. Together with his wife Anni Urbach (1905-1993), ${ }^{61}$ he left Vienna in the spring of 1939 and settled in the United States; in 1941 he got a research position at the Institute for Optics, University of Rochester, and was employed as a researcher at Eastman Kodak, in Rochester, NY, using the knowledge of infrared sensitive phosphors he gained in Vienna.

In spring of 1940, the Przibram couple finally succeeded in leaving Austria for Brussels after having payed Reichsfluchtsteuer, one of the Nazi measures to rob 
Jews before they were allowed to cross borders of the Deutsches Reich. Brussels was planned as an intermediate stop on the way to England. Przibram already had an offer arranged by the Society for the Protection of Science and Learning at the Holt Radium Institute (now the Christie Cancer Hospital) in Manchester. They wanted to join their children in England as soon as possible. ${ }^{62}$ On May 10, 1940, seven German armies started to attack the neutral states Belgium, Luxemburg, and the Netherlands. On May 17, Brussels surrendered without a fight. The Przibrams had been trapped.

A similar, but deadly fate awaited Przibram's brother, Hans. He and his wife had emigrated to Amsterdam, where he was invited to pursue his former research at the Biologische Versuchsanstalt in Vienna at the University of Amsterdam when they were summoned by the Nazis in April 1943 to leave for Theresienstadt in Northern Bohemia. ${ }^{63}$ On April 21, he reported to his brother Karl in Brussels: "We had been prompted to go to Theresienstadt" [Wir sind aufgefordert worden, nach Theresienstadt zu fahren]. It is likely that the Przibrams did not realize what "Theresienstadt" implied-a Nazi concentration camp. On May 20, 1944, Hans Przibram died there of prostration; his wife Elisabeth took her life by poison. ${ }^{64}$

During the years in exile in Brussels, Przibram was supported by the company Union Minière du Haute Katanga, a major uranium supplier with excellent contacts to Meyer and the Radium Institute. Przibram's outstanding knowledge of English and French eased his work for the company when refereeing scientific literature. ${ }^{65} \mathrm{He}$ lived relatively unmolested, in open contact with his children

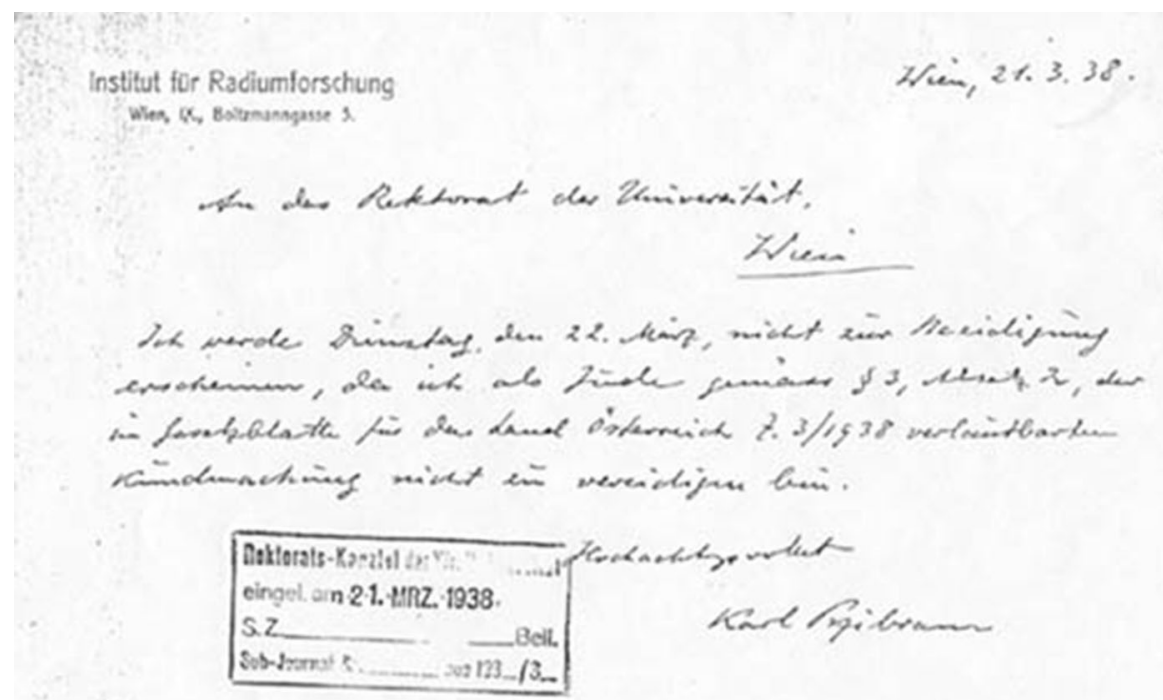

Fig. 4. Przibram's postcard of March 21, 1938. Courtesy of the Dokumentationsarchiv des österreichischen Widerstands 


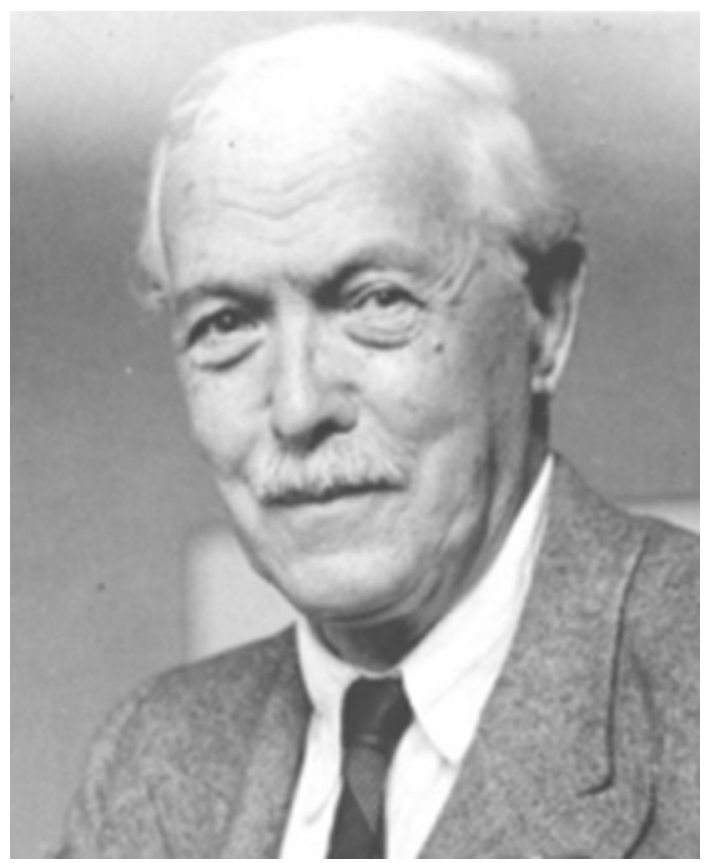

Fig. 5. Karl Przibram around 1955. Courtesy of the Archiv Österreichische Akademie der Wissenschaften

thanks to the war post service of the Red Cross. During the weeks of the fallback of the German army and until Belgium was liberated by the Allied Forces, the Przibrams were hidden by members of the Belgium resistance. ${ }^{66}$

After the liberation of Belgium, the Österreichische Freiheitsfront-Front National Autrichien legalized its hitherto clandestine activities. This resistance organization had about 750 members, mostly communists; Karl Przibram was president of the executive committee of the Freiheitsfront. Until the official installation of an Austrian diplomatic representation in Belgium, Przibram was authorized to act in the interests of Austrians in Belgium, a clear sign of his high reputation. ${ }^{67}$

In June 1945, Przibram gave a lecture for the Freiheitsfront on the discovery of Radium and Austria ("Die Entdeckung des Radiums und Österreich"). In November 1945, a conference "Science in Austria" was convened at Burlington House of the Chemical Society in London as a "Meeting of British and Austrian Scientists in Support of the Restoration of Science in Austria." ${ }^{68}$ The conference was organized by the Free Austrian Movement, the largest Austrian exile organization in Great Britain. Besides eminent British scholars (among others, Sir D'Arcy W. Thompson (chair), P. M. S. Blackett, and L. Hogben) who addressed 


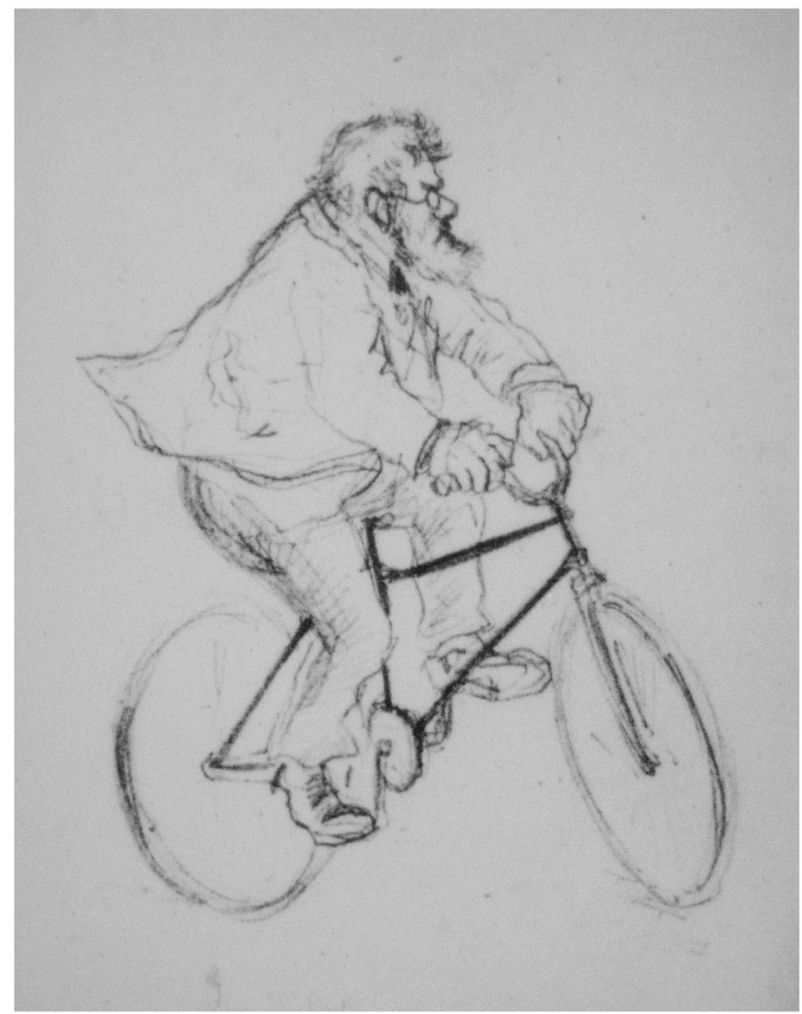

Fig. 6. Ludwig Boltzmann riding a bicycle-the principles of mechanics. Cartoon by Karl Przibram

the meeting, Przibram spoke on behalf of Austrian scientists, and in his statement plead for remigration of exiled scientists to Austria and expressed his hope for support from outside: "Only emerging out of an isolation of seven years duration, and without trustworthy information as to the state in which the Austrian Universities actually are, it is difficult to judge future possibilities... Much, of course, will depend upon the willingness of our leading men of science now in foreign parts to return to Austria and the hardship of reconstruction, and also upon the help given by colleagues in other countries." ${ }^{69}$ In conclusion, Przibram expressed his hopes for the future well-being of the Radium Institut and the Biologische Versuchsanstalt:

The first is the "Institut für Radiumforschung" of the Vienna Academy of Sciences, with which I was connected for 18 years. I hope to see Professor Stefan Meyer once more the Head of the Institut, whose very heart and soul he was since its foundation in 1910. 
The second institute I wish to refer to is the "Biologische Versuchsanstalt" in the Vienna Prater, founded conjointly with L. Portheim and W. Figdor by my late brother, Hans Przibram. It was my brother's aim to make the Institute a centre not only of experimental, but also of 'quantitative' biology, and I hope this trend of research may be continued there, in memory of him who died a victim of Nazi barbarism. ${ }^{70}$

During the last days of the liberation of Vienna by the Red Army, the Biologische Versuchsanstalt came under heavy fire and the building was destroyed. The Academy of Sciences soon after sold the ruins. Meyer was reinstated as head of the Radiuminstitut and continued until his retirement in 1947.

Only a handful of scientists forced to leave the country after March 1938 actually returned to Austria; Przibram was among them. ${ }^{71}$ The willingness of academia and government to actively foster remigration and invite scientists to come back was limited. Otherwise, they had to admit that they had been part and parcel of the game played long before the Nazis took power, the intentional discrimination targeting Jewish academics. To invite Jewish academics to come back would have been a concession of the academic elite in contrast to their former discriminating policy since the 1920s. The conservative academic elite of the pre-Nazi era dominated university life after 1945, keeping competition at a low level-a silent agreement of sort of an "auto-provincialisation" formed academic life in Austria until the late 1960s. ${ }^{72}$

In January 1946 Przibram contacted the University of Vienna, signaling his willingness to return to Austria: "I would appreciate very much to return to my home country and to resume an appropriate sphere of influence I believe to be entitled regarding my former activity, and as a partial compensation for injustice suffered, thus contributing to the reconstruction [of the country]." ${ }^{73}$ In his correspondence with the University of Vienna, Przibram rightly lodged the claim of compensation for the injustice he suffered, "in terms of the Law of Compensation with regard to the injustice suffered and my former activity in an ordinary professorship of one of the physics institutes."74

\section{Back to Vienna-Przibram's Later Years}

After Przibram's return as one of the few returnees in the sciences, he was reinstalled on June 1, 1946, into his former position as extraordinary professor at the Radium Institute. After he had already taken office as director of the II. Physikalisches Institut in 1946, he finally was appointed ordinary professor and chair of the institute on March 17, 1947-after long-standing urgent interventions by the university at the Ministry of Education.

Przibram now was responsible for a good part of the education in experimental physics at the University of Vienna. He started a four-term cycle of introductory lectures in experimental physics and practical courses for beginners and advanced 
students, the core of the physics curriculum for a long time after Przibram retired when his successors retained the curriculum he had successfully initiated.

We only are able to conjecture about the reasons Karl Przibram decided to return to his home country seeking some sort of continuity of the activities he was forced to leave in 1939. Certainly, his political engagement for Austria in exile in Belgium reveals a strong personal motivation, a patriotic motive to get engaged in the reconstruction of scientific life in Austria after the end of the Nazi régime as he had made clear in his letters to the University of Vienna authorities. But, beside these political and emotional motives, there had been practical constraints leading to his decision to return. Despite the deplorable situation in Vienna after the end of the war, here he had a home, a comfortable house restituted after it had been "Arianized" in 1939. When he came back to Vienna in 1946, 68 years of age and close to retirement, he had been out of practical experimental work for seven long years, an eternity for a working experimentalist. Realistically, he had to start afresh with little to no hope of linking his former activities at the Radium Institute with the situation now prevailing at the university - times had completely changed with respect to faculty, students, infrastructure, money, and, last but not least, the significance of his own field of research had been changing rapidly after World War II. The physics of semiconductors now was the most rapidly growing branch of solid state physics. To look forward and find new tasks was the only strategy at stake: An ordinary professorship at his old university provided the basis for contributing to the reconstruction of scientific life in Austria-and here he started with the necessary first step of renewing the physics curriculum from scratch, with enduring success. The crystal maze now was the task of a younger generation of experimental physicists.

In September 1950, Przibram, now 72 years old, reached retirement age, but stayed in office as honorary professor until his successor, Erich Schmid (18961983), a metal physicist, was appointed. His last decades were marked by awards for his life's work, for his untiring labor on behalf of the scientific community and the society at large: the Prize for Natural Sciences (Preis der Stadt Wien für Naturwissenschaften) in 1955 and the Honorary Medal in Gold 1958 (Ehrenmedaille der Bundeshauptstadt Wien), both awarded by the City of Vienna; the highest award of the Austrian Academy of Sciences, the Schrödinger Prize in 1963. In 1957 he was made Honorary Member of the Austrian Physical Society, which he had helped to found after 1945, and ten years later he was made Honorary Member of the Chemisch-Physikalische Gesellschaft, founded in Vienna in 1869 by Loschmidt and Stefan, among others (figure 5).

In 1950 Przibram was elected ordinary member of the Austrian Academy of Sciences, possibly filling the gap Stefan Meyer left when he passed away in 1949. Among the numerous posts he held, we mention his chair of the Kommission für Strahlenforschung und Strahlenschutz (1958 to 1965) and the Kuratorium des Instituts für Radiumforschung (1950 to 1965), both bodies belonging to the Austrian Academy of Sciences. Until 1969 he was president of the Vereinigung 
Österreichischer Wissenschafter, the Austrian branch of the Pugwash Movement, and member of the Österreichisches Hiroshima-Komitee.

After his retirement, he was welcomed back to the Radium Institute, where he continued his scientific work from 1951 until 1963, aged 85. In the preface of his monograph Verfärbung und Lumineszenz, dated Christmas 1952, Przibram noted that the first draft of this book had been written during his forced inactiveness after March 1938; retirement now provided ample time and leisure to rewrite and finish the monograph. It was published by Springer-Verlag Wien in 1953 and still is one of the most valuable source books for mineral physics and luminescence, last but not least because of its 929 references. The subtitle of the monograph reads Beiträge zur Mineralphysik, contributions to mineral physics, indicating the strong preference for Przibram's work for mineralogy. ${ }^{75}$ English and Russian translations soon followed. The first part the book comprises theoretical considerations and experimental techniques regarding coloration phenomena and luminescence, especially of halides as a model substance, giving a comprehensive, mostly phenomenological description of the state of crystal physics up to the early 1950s with special emphasis on the work done under his supervision at the Radium Institute. (It is interesting to note that-not completely uncommon for a book of that time and an author of the older generation of experimentalists-quantum mechanical explanations for solid state physics phenomena are lacking.)

As one of the pioneers of color center physics, Karl Przibram, now aged 84, attended the 3rd International Conference on Color Centers in the Alkali Halides in Stuttgart in August of 1962. This was his last public appearance in the scientific community to which he had dedicated his life's work on the study of colored rock salt and the functional dependencies between the properties of crystals and their coloration. The summary of his talk hints at questions opened since the days he began his studies, but he sounded like a voice from the distant past when he referred to the settled problem of "macroscopic cavities" (macroscopic defects): "A few questions are indicated which seems to deserve further study. Is there a continuous transition from F-centers by way of higher centers and the vacancies containing colloidal particles to microscopic and macroscopic cavities? In natural rock salt, all of these lattice disturbances, except the F-centers, tend to be located in certain layers of the crystal."76

Przibram's name became known to a wider group of people interested in physics, in particular historians of science, with his editorial work on behalf of the Austrian Academy of Sciences of letters on wave mechanics written by Schrödinger, Planck, Einstein, and Lorentz. This collection was published in 1963 with a subsequent English translation in $1967 .{ }^{77}$ Another side of this richly gifted man was his profound ability to draw, only outperformed by his brother Hans. Karl Przibram's caricatures, in particular those of Boltzmann, decorate a range of books about his teacher. ${ }^{78}$ (figure 6) 
In 1970 Przibram suffered a heavy blow: after fifty-one years of happy marriage, his wife Else passed away. His last years were overshadowed by deteriorating hearing and eye problems that rendered him nearly blind. Until his final days, he remained a lucid thinker, interested in modern physics as well as politics. Przibram was a wise man full of fine humor, a gentleman of English manners blended with a touch of turn-of-the-century Vienna. After Stefan Meyer's death in 1949, he was the doyen of the physics community of his country, a country that did not always fare as well as he. ${ }^{79}$

Karl Przibram died at the age of 95 years at his house in Wien-Unter-St.-Veit, Mantlergasse 16a, on August 10,1973. He is buried at the family crypt at the Jewish section of Vienna's Central Cemetery (Zentralfriedhof).

\section{Acknowledgements}

Open access funding provided by University of Vienna. I am indebted to late Dr. Doris Baumann, Vienna and Heini Przibram, Wrexham, UK for sharing information on Karl and Hans Przibram. The help of the Archiv der Österreichischen Akademie der Wissenschaften, in particular Dr. Stefan Sienell, is gratefully acknowledged. My sincere thanks goes to Joseph D. Martin, Editor-inChief of Physics in Perspective, for his thoughtful suggestions to improve this paper, clarifying comments, and valuable editorial help.

Open Access This article is distributed under the terms of the Creative Commons Attribution 4.0 International License (http://creativecommons.org/licenses/by/4.0/), which permits unrestricted use, distribution, and reproduction in any medium, provided you give appropriate credit to the original author(s) and the source, provide a link to the Creative Commons license, and indicate if changes were made.

Publisher's Note Springer Nature remains neutral with regard to jurisdictional claims in published maps and institutional affiliations.

\section{References}

${ }^{1}$ Robert K. Merton, On the Shoulders of Giants: A Shandean Postscript: The Post-Italianate Edition, repr. ed. (1965; University of Chicago Press, 1993).

${ }^{2}$ Berta Karlik und Erich Schmid, Franz Serafin Exner und sein Kreis. Ein Beitrag zur Geschichte der Physik in Österreich (Wien: Verlag der Österreichischen Akademie der Wissenschaften, 1982).

${ }^{3}$ Michael Stölzner, "Franz Serafin Exner's Indeterminist Theory of Culture," Physics in Perspective 4, no. 3 (2002), 267-319; Michael Stölzner, "Vienna Indeterminism: Mach, Boltzmann, Exner," Synthese 119, no. 1 (1999), 85-111; Deborah R. Coen, Vienna in the Age of Uncertainty: Science, Liberalism, and Private Life (Chicago: University of Chicago Press, 2007); Climate in Motion: Science, Empire, and the Problem of Scale (Chicago: University of Chicago Press, 2018). 
${ }^{4}$ Carl E. Schorske, Fin-De-Siècle Vienna: Politics and Culture (Cambridge: Cambridge University Press, 1961).

${ }^{5}$ Maria Rentetzi, Trafficking Materials and Gendered Experimental Practices: Radium Research in Early Twentieth Century Vienna (New York: Columbia University Press, 2007); Silke Fengler and Carola Sachse, Kernforschung in Österreich: Wandlungen eines interdisziplinären Forschungsfeldes 1900-1978 (Wien: Böhlau Verlag, 2012); Silke Fengler, Kerne, Kooperation und Konkurrenz: Kernforschung in Österreich im internationalen Kontext (1900-1950) (Wien: Böhlau Verlag, 2014); Gerd B. Müller, Vivarium: Experimental, Quantitative, and Theoretical Biology at Vienna's Biologische Versuchsanstalt (Cambridge, MA: MIT Press, 2017).

${ }^{6}$ Friedrich Schey (b. Günz, 1815, d. Lainz bei Wien, 1881) was knighted ("Ritter von Koromla"), in 1863 and elevated to "Freiherr" (baron) in 1869. Schey's own bank had been shuttered in 1881 after his death. His uncle Philipp Schey (b. Günz, 1798, d. Baden bei Wien, 1881) was the first Hugarian Jew to be ennobled by the Emperor in 1859 for his service in financial and material regards in support of the Imperial troops to bring down the revolution of 1848. Philipp Schey was knighted ("Ritter von Koromla") in 1859 and upraised to "Freiherr" (baron) in 1871. Being a bachelor, he endowed part of his fortune to build a synagogue in Günz. Österreichisches Biographisches Lexikon 1815-1950, Bd. 10 (Lfg. 47) 1965, 100-101.

${ }^{7}$ Josef Schey, Österreichisches Biographisches Lexikon 1815-1950, Bd. 10 (Lfg. 47) 1965, 101. From 1907 Schey was lifelong member of the Herrenhaus, the upper chamber of the Parliament.

${ }^{8}$ Oliver Rathkolb, ed., Der lange Schatten des Antisemitismus: Kritische Auseinandersetzungen mit der Geschichte der Universität Wien im 19. und 20. Jahrhundert. (Göttingen: V \& R unipress, Vienna University Press, 2013). Regina Fritz, Grzegorz Rossolinski-Liebe, and Jana Starek, ed., Alma mater Antisemitica: Akademisches Milieu, Juden und Antisemitismus an den Universitäten Europas zwischen 1918 und 1939. Beiträge zur Holocaustforschung des Wiener Wiesenthal Instituts für Holocaust-Studien (VWI), Band 3 (Vienna: New Academic Press, 2016).

${ }^{9}$ Obituary of Joseph Unger, Almanach der kaiserlichen Akademie der Wissenschaften 63, Jg. 1913 (1914), 458.

${ }^{10}$ Gustav Przibram started his carrier as a writer relatively late in life in the 1880 s. His work includes: the drama Die Socialisten: Drama in 5 Acten, Vienna 1881; a work in verse, Der Golem: Eine Prager Sage, Vienna 1882, an adaption of the Golem saga, dedicated to his uncle Sigmund von Hofmannsthal (1805-1883), who "in my childhood days / often carried me in his arms [in meiner Kindheit Tagen/Mich oft auf [seinem] Arm getragen]"; and a volume of poems Gedichte, Vienna 1893. Martina Niedhammer, Nur eine "Geld-Emanzipation"?: Loyalitäten und Lebenswelten des Prager jüdischen Großbürgertums 1800-1867 (Göttingen: Vandenhoeck \& Ruprecht, 2013), 217.

${ }^{11}$ Walter Przibram died in Bonn on February 22, 1898, at the age of 25 years; he was a student of Ernst Mach at the University of Vienna. Little is known about Walter Przibram; he published "Versuch einer Darstellung der Empfindungen" (Wien: A. Hölder, 1898), in Zeitschrift für Psychologie und Physiologie der Sinnesorgane 20 (1899).

${ }^{12}$ Friederike Przibram was married to the lawyer Dr. Alfred Lederer (1872-1943); their son was the biochemist of natural substances Edgar Lederer (1908-1988); together with the Viennese born Nobel Prize winner in chemistry of 1938, Richard Kuhn (1900-1967) and A. Winterstein they contributed a paper in 1931 to a re-discovery and revival of adsorption chromatography, making it a widely used tool in biochemical research. As a Jew, Lederer had to leave Kuhn's laboratory at the University of Heidelberg in 1933 and finally settled in France in 1938 where he became professor of biochemistry at the Sorbonne in 1958.

13 "Der in meinem Elternhaus herrschende Geist war der des gebildeten jüdischen Bürgertums der liberalen Ära, mit seinem unbedingten Glauben an den Fortschritt und seiner Aufgeschlossenheit für 
alle Errungenschaften der Kunst und Wissenschaft. Zu meinen Onkeln gehörten die Juristen Josef Unger und Josef Schey sowie der Chemiker Adolf Lieben. Mein Vater selbst, übrigens ein begabter Dichter und voll tiefen sozialen Empfindens, interessierte sich sehr für die technischen Anwendungen der Naturwissenschaften. Er war an der Erfindung einer galvanischen Batterie beteiligt, mittels welcher er anfangs der achtziger Jahre unsere Wohnung beleuchtete." Berta Karlik, "Karl Przibram: Nachruf," Almanach der Österreichischen Akademie der Wissenschaften 12 (1974), 380.

1414 Karl Przibram, curriculum vitae (undated, probably 1905), Archiv der Universität Wien, Personalakt K. Przibram.

${ }^{15}$ Leopold Pfaundler von Hadermur, Österreichisches Biographisches Lexikon 1815-1950 (ÖBL), Band 8, Verlag der Österreichischen Akademie der Wissenschaften, Wien 1983. Przibram probably moved to Graz to shorten his waiting time for a place to do his experimental dissertation, which was limited in Vienna due to the dilapidated conditions of the building at Türkenstrasse 3, severely limiting working space for PhD students. See Berta Karlik und Erich Schmid, Franz Serafin Exner und sein Kreis: Ein Beitrag zur Geschichte der Physik in Österreich (Wien: Verlag der Österreichischen Akademie der Wissenschaften, 1982), 153. Przibram's first publication: "Beiträge zur Kenntnis des verschiedenen Verhaltens der Anode und Kathode bei der elektrischen Entladung," Wiener Berichte 108 (1899), 1161-71, 1899.

${ }^{16}$ Heinrich Benedikt, Damals im alten Österreich. Erinnerungen (München: Amalthea Verlag, 1979), 39-57.

${ }^{17}$ Wolfgang L. Reiter, "Zerstört und vergessen: Die Biologische Versuchsanstalt und ihre Wissenschaftler/innen,” Österreichische Zeitschrift für Geschichtswissenschaften 10, no. 4 (1999), 585614.

${ }^{18}$ The sum of 100,000 Kronen (crowns) could be roughly compared to the estimate of the total cost for the complete infrastructure of one of the new physics institutes of the University of Vienna, which was about 130,000 Kronen.

${ }^{19}$ Felix Ehrenhaft, "Über die Messung von Elektrizitätsmengen, die die Ladung des einwertigen Wasserstoffions oder Elektrons zu unterschreiten scheinen. Zweite vorläufige Mitteilung seiner Methode zur Bestimmung des elektrischen Elementarquantums," Anzeiger der Akademie der Wissenschaften in Wien 13 (1910), 215; "Über die Messung von Elektrizitätsmengen, die kleiner zu sein scheinen als die Ladung des einwertigen Wasserstoffions oder Elektrons und von dessen Vielfachen abweichen," Akadademie der Wissenschaften (Wien), Mathematisch-naturwissenschaftliche Klasse, Abt. 2a, Sitzungsberichte 119 (1910), 815-66; "Über eine neue Methode zur Messung von Elektrizitätsmengen an Einzelteilchen, deren Ladungen die Ladung des Elektrons erheblich unterschreiten und auch von dessen Vielfachen abzuweichen scheinen," Physikalische Zeitschrift 11 (1910): 619-30; "Der Nachweis von Elektrizitätsmengen, welche kleiner sind als die Ladung des Elementarquantums," Verhandlungen der Deutschen Physikalischen Gesellschaft 15 (1913), 1187; Wolfgang L. Reiter, "Felix Ehrenhaft 1879-1952: Enfant terrible in der Welt der submikroskopischen Teilchen-Entdecker der Photophorese," in R. Werner Soukup (Hg. im Auftrag der Universität Wien), Die wissenschaftliche Welt von Gestern. Die Preisträger des Ignaz L. Lieben-Preises 1865-1937 und des Richard Lieben-Preises 1912-1928 (Wien: Böhlau 2004), $155-65$.

${ }^{20}$ Karl Przibram, "Ladungsbestimmungen an Nebelteilchen I. Beiträge zur Frage des elektrischen Elementarquantums," Akademie der Wissenschaften (Wien), Mathematisch-naturwissenschaftliche Klasse, Abt. IIa, Sitzungsberichte 119 (1910), 869-935; "Ladungsbestimmungen an Nebelteilchen II," Akademie der Wissenschaften (Wien), Mathematisch-naturwissenschaftliche Klasse, Abt. IIa. Sitzungsberichte 119 (1910), 1719-53; R. A. Millikan, "A New Modification of the Cloud Method of Determining the Elementary Charge and the Most Probable Value of That Charge," Philosophical Magazine 19 (1910): 209-28. Felix Ehrenhaft, "Über die Messung von Elektrizitätsmengen, die die Ladung des einwertigen Wasserstoffions oder Elektrons zu 
unterschreiten scheinen. Zweite vorläufige Mitteilung seiner Methode zur Bestimmung des elektrischen Elementarquantums," Anzeiger Akadademie der Wissenschaften (Wien) 13 (1910), 215; Deborah R. Coen, "Die Fehler der Wissenschaftler, die Schwankungen der Natur und das Gesetz des radioaktiven Zerfalls, 1899-1926," in Kernforschung in Österreich. Wandlungen eines interdisziplinären Forschungsfeldes 1900 - 1978, ed. Silke Fengler and Carola Sachse (Wien: Böhlau Verlag, 2012), 300-307.

${ }^{21}$ Gerald Holton, "Subelectrons, Presuppositions, and the Millikan-Ehrenhaft Dispute," in The Scientific Imagination: Case Studies, 25-83 (Cambridge: Cambridge University Press, 1978), esp. 73 and notes on 313-17.

${ }^{22}$ Jean Perrin et al., "Diskussion" following "Die Beweise für die wahre Existenz der Moleküle," in Die Theorie der Strahlung und der Quanten. Verhandlungen auf einer von E. Solvay einberufenen Zusammenkunft (30. Oktober bis 3. November 1911). Mit einem Anhange über die Entwicklung der Quantentheorie vom Herbst 1911 bis Sommer 1913, ed. Arnold Eucken (Halle a. S.: Knapp, 1914). (Abhandlungen der Deutschen Bunsen Gesellschaft für angewandte physikalische Chemie 3, no. 7 (1911), 206-7.)

${ }^{23}$ Edmund Weiß, "Ladungsbestimmungen an Silberteilchen," Physikalische Zeitschrift 12 (1911), 630-33. The Collected Papers of Albert Einstein, vol. 3, The Swiss Years: Writings, 1900-1911, ed. Martin J. Klein, A. J. Kox, Jürgen Renn, and Robert Schulmann (Princeton: Princeton University Press, 1993), 509.

${ }^{24}$ Robert A. Millikan, The Electron (Chicago: University of Chicago Press, 1917), 153, 163.

${ }^{25}$ Ehrenhaft, Curriculum Vitae (undated), Österreichische Zentralbibliothek für Physik in Wien, Ehrenhaft Nachlaß, Plesch-Papiere. Emphasis added.

${ }^{26}$ See N. A. Fuchs, Mechanics of Aerosols (London: Pergamon Press, 1964), 38.

${ }^{27}$ See Othmar Preining, "The Millikan-Ehrenhaft Dispute and the Creation of Aerosol Mechanics," paper delivered at the American Aerosol Society, Denver, October 1997. The author thanks the late O. Preining, a student of Ehrenhaft in the 1950s, for kindly providing the manuscript of his lecture. See also: Agnieszka Kupc, "Experimental Study of Nucleation in Different Vapors and Its Temperature Dependence and the Effect of Particle Properties on the Response of Condensation Particle Counter" (PhD dissertation, Universität Wien, 2013).

${ }^{28}$ Karl Przibram. Pflügers Archiv der Physiologie 153 (1913), 401-5.

${ }^{29}$ Albert Einstein, "Über die von der molekularkinetischen Theorie der Wärme geforderte Bewegung von in ruhenden Flüssigkeiten suspendierten Teilchen," Annalen der Physik 322, no. 8 (1905), 49-56.

${ }^{30}$ D. Selmeczi, S. F. Tolić-Nørrelykke, E. Schäffer, P. H. Hagedorn, S. Mosler, K. Berg-Sørensen, N. B. Larsen, and H. Flyvbjerg, "Brownian Motion after Einstein: Some New Applications and New Experiments," Acta Physica Polonica B 38, no. 8 (2007), 2422.

${ }^{31}$ Felix M. Exner, "Notiz zu Brown's Molecularbewegung," Sitzungsberichte der kaiserlichen Akademie der Wissenschaften IIa, 109 (1900), 843-47; Marian von Smoluchowski, "Zur kinetischen Theorie der Brownschen Molekularbewegung und der Suspensionen," Annalen der Physik 326 (1906), 756-80; Albert Einstein, "Über die von der molekularkinetischen Theorie der Wärme geforderte Bewegung von in ruhenden Flüssigkeiten suspendierten Teilchen," Annalen der Physik 322, no. 8 (1905), 549-60. See also: Deborah R. Coen, Vienna in the Age of Uncertainty: Science, Liberalism and Private Life (Chicago: University of Chicago Press, 2007), 263-69.

32 Jean Perrin, "Mouvement brownien et realité moléculaire," Annales de chimie et de physique 18, no. 8 (1909), 5-114.

${ }^{33}$ Wolfgang L. Reiter, "Stefan Meyer: Pioneer of Radioactivity," Physics in Perspectives 3, no. 1 (2001), 106-27. 
${ }^{34}$ Stefan Meyer, "On the Change of Colour of Kunzite by Becquerel-Radiation," Ion 1, no. 4 (1909), 260; "Über das Verhalten von Kunzit unter Einwirkung von Becquerelstrahlung," Physikalische Zeitschrift 10 (1909), 483-84. C. Dölter, Das Radium und die Farben (Steinkopf: Dresden 1910); Die Farben der Mineralien (Braunschweig: Sammlung Vieweg, 1925).

${ }^{35}$ Luminescence is the modern term, including fluorescence (light emission stops more or less immediately after irradiation and the system returns to its initial state) and phosphorescence (afterglow at the end of irradiation before the system returns to its initial state).

${ }^{36}$ Karl Przibram and Stefan Meyer, "Über die Verfärbung von Salzen durch Becquerelstrahlen und verwandte Erscheinungen,” Wiener Berichte 123 (1914), 653-63.

${ }^{37}$ See Jürgen Teichmann and Krzysztof Szymborski, "Point Defects and Ionic Crystals: Color Centers as the Key to Imperfections," in Out of the Crystal Maze: Chapters from the History of Solid-State Physics, ed. Lillian Hoddeson, Ernest Braun, Jürgen Teichmann, and Spencer Weart, 236-316 (New York: Oxford University Press, 1992), 247. The authors state that the starting point of the Göttingen (R. W. Pohl) and Vienna alkali halide research was Röntgen's long and detailed 1921 publication on rock salt. W. C. Röntgen, "Über die Elektrizitätsleitung in einigen Kristallen und über den Einfluss einer Bestrahlung darauf," Annalen der Physsik 64 (1921) 1-195. Röntgen's 1921 paper is not listed among the references in Pribram's 1953 monograph, which is an indication that research in Vienna had a different starting point. In this context, it has to be noted that Meyer and Przibram, in a paper published in 1912, found an enhanced external photoelectric effect in fluorite, kunzite, and glass after irradiation by radium rays. Stefan Meyer and Karl Przibram, "Über einige neuere Erscheinungen bei der Beeinflussung von Gläsern und Mineralien durch Becquerelstrahlen," Wiener Berichte 121, no. 2a (1912), 1413. Karl Przibram, Verfärbung und Lumineszenz. Beiträge zur Mineralphysik (Wien: Springer-Verlag 1953), 49.

${ }^{38}$ Teichmann and Szymborski, "Point Defects" (ref. 37), 243.

${ }^{39}$ Erika Renate Wallis, nèe Przibram (1926-).

${ }^{40}$ For information on the Ignaz-L.-Lieben Prize, see "Die Ignaz-Lieben-Gesellschaft," accessed July 31, 2019, http://www.i-l-g.at/home/.

${ }^{41} 41$ Karl Przibram, "Über die Phosphoreszenz durch Becquerelstrahlung verfärbter Mineralien," Wiener Berichte 130, no. 2a (1921), 256.

42 "Die Träger der Fremdfärbung, kurz Zentren genannt, sind amikroskopische Gebilde mit einem einfachen charakteristischen Absorptionsspektrum." B. Gudden und R. W. Pohl, "Zur lichtelektrischen Leitung bei tiefen Temperaturen,” Zeitschrift für Physik 34 (1925), 249. English translation in Hoddeson et al., eds., Crystal Maze (ref. 37), 249.

${ }^{43}$ Karl Przibram, Verfärbung und Lumineszenz: Beiträge zur Mineralphysik (Wien: SpringerVerlag, 1953), 55. Karl Przibram and Maria Belar, "Die Verfärbung durch Becquerelstrahlen und die Frage des blauen Steinsalzes," Wiener Berichte, 132, no. 2a (1923), 261. For Farbzentren (color centers) see K. Przibram, "Zur Theorie der Verfärbung des Steinsalzes durch Becquerelstrahlen," Sitzungsberichte der Akademie der Wissenschaften (Wien), Mathematisch-naturwissenschaftliche Klasse 135, no. 2a (1926), 197-211, and 136 (1927), 679.

${ }^{44}$ Karl Przibram and Elisabeth Kara-Michailova, "Über Radiolumineszenz und Radio-Photolumineszenz," Wiener Berichte 131, no. 2a (1922), 511-30, on 520; "Über Radiolumineszenz und Radio-Photolumineszenz, II. Mitteilung,” Wiener Berichte 132, no. 2a (1923) 285-98.

${ }^{45}$ Hevesy had been working at the Radium Institute in 1920 on the diffusion and ionic conduction in ionic crystls. Teichmann and Szymborski, "Point Defects" (ref. 37), 241, 261.

${ }^{46}$ Teichmann and Szymborski, "Point Defects" (ref. 37), 262. Karl Przibram, "Die Verfärbung des gepressten Steinsalzes," Wiener Anzeiger, January 19, 1927; Wiener Berichte 136, no. 2a (1927). 43. Urbach et al. discuss the Lockerstellenhypothese in Franz Urbach and Georg Schwarz, "Zur 
Lumineszenz der Alkalihalogenide. III. Thermolumineszenzmessungen; zur Lockerstellenhypothese," Wiener Berichte 139, no. 2a (1930), 492-95.

${ }^{47}$ Franz Urbach, "Zur Lumineszenz der Alkalihalogenide. I. Vorbemerkungen und orientierende Beobachtungen," Wiener Berichte 139, no. 2a (1930), 353-62; "Zur Lumineszenz der Alkalihalogenide. II. Mitteilung," Wiener Berichte 139, no. 2a (1930), 363-72. Franz Urbach and Georg Schwarz, "Zur Lumineszenz der Alkalihalogenide. III. Thermolumineszenzmessungen; zur Lockerstellenhypothese," Wiener Berichte 139, no. 2a (1930), 483-95.

${ }^{48}$ Karl Przibram, Verfärbung und Lumineszenz. Beiträge zur Mineralphysik (Wien: SpringerVerlag 1953), 235-72.

${ }^{49}$ O. R. Frisch, "Über die Wirksamkeit von langsamen Kathodenstrahlen auf Steinsalz," Mitteilungen des Instituts für Radiumforschung (1927). Other friends of Urbach included the psychoanalyst Siegfried Bernfeld (1892-1953) and the philosopher Karl R. Popper (1902-1994).

${ }^{50}$ Victor Weisskopf, Joy of Insight: Passion of a Physicist (New York: Basic, 1991), 25.

${ }^{51}$ Franz Urbach, "Über Lumineszenz und Absorption, insbesondere des mit Becquerelstrahlen behandelten Sylvin," Mitteilungen des Instituts für Radiumforschung 185 (1926).

52 Teichmann and Szymborski, "Point Defects" (ref. 37), 240.

${ }^{53}$ Wolfgang L. Reiter, "Hans Thirring-ein Leben im Spannungsfeld von Physik und Politik," in Physik, Militär und Frieden: Physiker zwischen Rüstungsforschung und Friedensbewegung, ed. Christian Forstner and Götz Neudeck (Wiesbaden: Springer Spektrum, 2018), 143-63.

${ }^{54}$ Reiter, "Stefan Meyer" (ref. 33), 116; Elizabeth Rona, How It Came All About: Radioactivity, Nuclear Physics, Atomic Energy (Oak Ridge: Oak Ridge Associated Universities, 1978), 15-16.

${ }^{55}$ Roger H. Stuewer, The Age of Innocence. Nuclear Physics between the First and Second Wars (Oxford: Oxford University Press, 2018), 56-58.

${ }^{56}$ Stuewer, Age of Innocence (ref. 55), 57. Maria Rentetzi, Trafficking Materials and Gendered Experimental Practices: Radium Research in Early 20 ${ }^{\text {th }}$ Century Vienna (New York: Columbia University Press, 2008), 100.

57 "Ich werde Dienstag, den 22. März nicht zur Vereidigung erscheinen, da ich als Jude gemäß Paragraph 3, Absatz 2, der im Gesetzblatt für das Land Österreich Z. 3/1938 verlautbarten Kundmachung nicht zu vereidigen bin. Hochachtungsvollst, Karl Przibram" Postcard dated March 21, 1938, Archiv des Dokumentationsarchivs des österreichischen Widerstands.

${ }^{58}$ Wolfgang L. Reiter, "Österreichische Wissenschaftsemigration am Beispiel des Instituts für Radiumforschung der Österreichischen Akademie der Wissenschaften," inVertriebene Vernunft II, Emigration und Exil österreichischer Wissenschaft, ed. Friedrich Stadler (Wien: Verlag Jugend und Volk, 1988), 709-29. See also: Reiter, "Stefan Meyer" (ref. 33).

${ }^{59}$ Heinrich (Heini) Przibram (1918-).

${ }^{60}$ Friedrich (Frederick) V. Meyer (1908-2004).

${ }^{61}$ Anni Urbach, who was working with Przibram's group as a freelance researcher, was the daughter of the psychoanalyst and founding member of Sigmund Freud's Psychologischer Mittwochgesellschaft in 1902, Paul Federn (1871-1950). Federn emigrated to the United States in 1938.

${ }^{62}$ Heini Przibram, letter to the author, January 1, 1989.

${ }^{63}$ Wolfgang L. Reiter, "Zerstört und vergessen: Die Biologische Versuchsanstalt und ihre Wissenschaftler/innen," Österreichische Zeitschrift für Geschichtswissenschaften 10, no. 4 (1999), 585614.

${ }^{64}$ In a private communication to the author Doris Baumann, daughter of Hans Przibram, conjectured that the Pribram couple had not been forced to leave Amsterdam but more or less 
voluntarily went to Theresienstadt on the grounds that Theresienstadt, situated in northern Bohemia, was relatively near to Vienna.

${ }^{65}$ These reports are now deposited at the Archiv der Österreichischen Akademie der Wissenschaften, Nachlaß Przibram, Archiv der Österreichischen Akademie der Wissenschaften, Institut für Radiumforschung, K. 37.

${ }^{66}$ Heini Przibram, letter to the author, January 1, 1989.

${ }^{67}$ Österreichische Staatskanzlei/auswärtige Angelegenheit, letter to Karl Przibram, November 27, 1945, Zl. 2001-pol/1945, in Ulrich Weinzierl, ed., Österreicher im Exil, Belgien 1938-1945: Eine Dokumentation (Wien: Dokumentationsarchiv des österreichischen Widerstands, 1987), 5, 520A.

${ }^{68}$ Wolfgang L. Reiter, "Wissenschaft im Exil: Die Association of Austrian Engineers, Chemists and Scientific Workers in Great Britain," in Political Exile and Exile Politics in Britain after 1933, Yearbook of the Research Centre for German and Austrian Exile Studies 12, ed. Anthony Grenville and Andrea Reiter, 21-46 (Amsterdam: Brill, 2011).

${ }^{69}$ Science in Austria. Leaflet, Presented on the Occasion of the Meeting of British and Austrian Scientists in Support of the Restauration of Science in Austria, November 3, 1945. Chemical Society, Burlington House, London, 9-10. Dokumentationsarchiv des österreichischen Widerstands 6504.

${ }^{70}$ Science in Austria (ref. 69).

${ }^{71}$ The only other physicist in exile who came back to Vienna was Felix Ehrenhaft. He returned in April 1947 as US-Guest Professor, and in autumn 1947 he took the position of an ordinary professorship of the University Vienna at the I. Physikalisches Institut affiliated with the III. Physikalisches Institut, giving Ehrenhaft a strong position within the faculty, which he extensively used to make trouble by inveighing against his colleagues at the Ministry for Education and ridiculing traditional physics as "Schulphysik" (school physics). Paul Feyerabend (1924-1994), one of Ehrenhaft's students, was fascinated by his more unorthodox lectures, for example on magnetic monopoles.

${ }^{72}$ Christian Fleck, "Autochthone Provinzialisierung: Universität und Wissenschaftspolitik nach dem Ende der nationalsozialistischen Herrschaft in Österreich," Österreichische Zeitschrift für Geschichtswissenschaften 7, no. 1 (1997), 67-92.

73 "Ich würde gerne in die Heimat zurückkehren und einen entsprechenden Wirkungskreis übernehmen, auf den ich im Hinblick auf meine frühere Tätigkeit und als teilweise Wiedergutmachung des erlittenen Unrechts auch Anspruch zu haben glaube, und so meinen Beitrag zum Wiederaufbau beitragen." Archiv der Universität Wien, Personalakt Karl Przibram.

74 "im Sinne des Wiedergutmachungsgesetzes im Hinblick auf das erlittene Unrecht und meine frühere Tätigkeit auf ein Ordinariat und eines der physikalischen Institute." Archiv der Universität Wien, Personalakt Karl Przibram.

${ }^{75}$ Karl Przibram, Verfärbung und Lumineszenz: Beiträge zur Mineralphysik (Wien: SpringerVerlag, 1953).

${ }^{76}$ Teichmann and Szymborski, "Point Defects" (ref. 37), 287. Krzysztof Szymborski, "The Physics of Imperfect Crystals-A Social History," Historical Studies in the Physical Sciences 14, no. 2 (1984), 317-55, on 353.

${ }^{77}$ Karl Przibram, Briefe zur Wellenmechanik (Schrödinger, Plank, Einstein, Lorentz) (Wien: Springer-Verlag, 1963); Karl Przibram, ed., Letters on Wave Mechanics. Schrödinger, Planck, Einstein, Lorentz, trans. Martin J. Klein (New York: Philosophical Library, 1967).

${ }^{78}$ See, for example, Carlo Cercignani, Ludwig Boltzmann: The Man Who Trusted Atoms (Oxford: Oxford University Press, 1998); Ilse Maria Fasold-Boltzmann and Gerhard Ludwig Fasold, eds., Ludwig Boltzmann (1844-1906): Zum hundertsten Todestag (Wien: Springer-Verlag, 2006). 
${ }^{79}$ Berta Karlik, "Karl Przibram: Nachruf," Almanach der Österreichischen Akademie der Wissenschaften 124 (1975), 379-87.

Faculty of Historical and Cultural Studies, University of Vienna Universitätsring 1

A-1010 Vienna, Austria

e-mail: wolfgang.reiter@univie.ac.at 